\title{
A PRAGMATIC STUDY AND ITS TRANSLATION OF THE FACE CONCEPT IN DIANA PALMER'S CATTLEMANT'S PRIDE
}

By:

\section{Syaifulloh}

\begin{abstract}
This paper shows concept of face focused on positive and negative faces in the Diana Palmer's Cattlemant's Pride. The writer has tried to find forms of expressions containing positive and negative faces using qualitative content analysis method. From the findings and discussion, it is found that there are some forms of positive face under the categories of kidding and joking. Meanwhile in negative face, bold on record, deference and conventional indirectness. In terms of the translation, it can be said that the translation is good enough and tends to be free.
\end{abstract}

Key Words: pragmatic, translation, face concept

\section{INTRODUCTION}

Politeness in using language is a new horizon in linguistics, and up to now it has not been studied yet in the linguistic constellation; except in a pragmatic study. Politeness in using language, although called as a new horizon, has arisen attention from linguists and pragmatists. For example Aziz (200) studied how Indonesian people make refusal through their speech, where according to him it contains specific values of politeness. It also shows that there is a new field in the linguistic study, not only in the aspect of grammar, but also psychosocial and also ethics.

As a new field in the linguistics study, especially language in use, politeness in using languages should be paid attention, by experts, linguists, or language learners. Moreover, it is also important for each person to understand this politeness, since the nature of men as the speaking creature always makes verbal communication with good ethics.

Although in pragmatics politeness is paid some attention, the concept of ethics in using language has long been existing in any verbal communication of people. Traditionally, politeness in using language is regulated in the peoples' norms and morality, internalized in cultural context and local wisdom. The ethics in using language between the young and the old that have long existed in verbal communication have disappeared due to the negative westernization flow which brings a liberal ideology.

It is time that the concept of politeness in traditional use of language is "reread" theoretically in order to make a refreshment of ideology on how a language should be used politely. This paper may be used as a referent in using daily language where language is not only as an instrument of communication, but as a medium of realizing ethical and polite 
selves. It is important to make a reflection on the values of politeness in using a daily language, where language is not only an instrument of communication, but also the medium of polite and ethical self-realization.

Polite and ethical attitudes or language use are relative, depending on the social distance of speakers and hearers. Moreover, the meaning of politeness and good manners should also be understood as the same in general; where the two should be different. The term polite refers to grammatical orders of utterances based on the awareness that each person has a right to be served well, meanwhile good manners means any awareness of social distance (Thomas, 1995).

The paper will serve politeness theory which was popularized by Brown and Levinson. The theory which is written in brief and followed by examples from empirical data is aimed to open our horizon about the politeness in using language.

\section{Politeness Principles}

Being polite in general deals with the relationship between two participants who may be called 'oneself' and 'others'. The concept of politeness in a pragmatic study is described by some experts, among others Leech, Robin Lakoff, Bowl dan Levinson. Politeness principles posses some maxims namely tact, generosity, approbation, modesty, agreement and sympathy. These politeness principles deal with two conversation participants, namely self and other. The self is the speaker and the other, hearer (Dewa Putu Wijana,1996). Maxim is a linguistic rule in a lingual interaction; any rule determining its actions, uses and interpretations of the actions and utterances of the interlocutors. Moreover, the maxim also suggests us to express beliefs politely and to avoid impolite utterances.

\section{Brown - Levinson's Politeness Model}

\section{Face Wants}

In daily social interactions, people in general behave as if their expectation of their public self-image is respected by others. If a speaker says something that is threatening to others' expectation of their self-image, this act is called as Face Threatening Act (FTA). As an alternative, one may say something with possible lesser threat, called Face Saving Act (FSA). See the following example:

A neighbor is playing music loudly and there is a couple who is trying to sleep. The husband may do an FTA: "I will say to him to stop playing music now!" or the wife may also 
make a FSA: "Perhaps we can ask him to stop playing music since it is late and we need sleeping”.

\section{Negative dan Positive Face}

According to Brown and Levinson, negative face is the basic claim to territories, personal preserves, and rights to non-distraction dan positive face is the positive and consistent image people have of themselves, and their desire for approval. In other words, negative face is a need to be independent and positive face is a need to any connection. Therefore, it can be inferred that FSA gives an orientation into negative face and a priority to the interest of other people, even, including a sorry for any disturbance made. Such FSA is called negative politeness, meanwhile the FSA with the orientation into one's positive face tend to show solidarity and stresses that the two parties (speaker and hearer) want the same thing and purpose. This FSA is called positive politeness.

\section{Negative and Positive Politeness}

Negative politeness pays attention to negative face, by determining the distance between a speaker and hearer and will not bother other's area. The speaker uses it to avoid an coercion, and gives some choices to the hearer. Speaker may avoid an image of coercing others by giving any stresses to others' interest by using apology, or by asking question that may arise "no" answer. For instance, in a student center, we want some help to mention an address of a site we need to Achmad:

"Excuse me, I don't mean to bother you, would you mind letting me know the address of the site of the lecturer we talked about this morning?"

Another example:

"Excuse me, may I borrow five hundred rupiah, ehmm, if you don't need it now?"

There is a choice that may influence the levels of politeness. The higher the possibility of "no" answer, the better the politeness of the utterance.

Positive politeness is intended to save something by applying closeness and solidarity, usually in friendship, and this makes others feel safe and stresses that the two parties have the same objective. For example, we are in the student center and we need some help, now we need some favors from our friend, Achmad.

"Achmad, you have good and admirable memory, it will be better if you gives me the address of a site intended by Anton this morning." 


\section{Superstrategies in Politeness}

In a speech act, we always have many expressions of an utterance. Brown and Levinson (1987) suggests some super strategies for language users in order to communicate in a polite way (cited from Yule, 1996, pp.62-66)." The next example will clarify the concept of super strategies. For example, we were doing a test, then we realized that we forgot to bring a pen. But we know that our classmates would give use some help. In this case, first we should make a decision whether to say something or not.

a. Not to say anything

We can directly look for something in our bag without saying anything while waiting for our classmates to ask for or to offer help. A "Not to say anything" approach might be successful or unsuccessful. This depends on how other interprete our actions.

b. Saying something: off record

If we decide to say something, we can say "Oh dear, I forgot my pen". It is similar with "not to say anything" approach, saying something: this off record also possesses possibility to succeed to fail. There is not any guarantee that other must understand our intention.

c. Saying something: on record

Contrary to the off record statement, we express our need by directly say to someone. The most explicit way to say our needs is by saying on record strictly. We can directly ask for help by saying : "Give me a pen!” An explicit demand by following Grices maxims is really direct and explicit. But, this may threat our interlocutor's face if the demand is considered as an order. To avoid such thing, we should avoid the matter, we should always make face saving acts using strategies of positive and negative politeness to muffle threats.

The strategy of positive politeness is oriented into repair the threat of hearer's positive face. When we make use of positive politeness, try to imagine that the hearer has the same basic or even has a good relationship with us. Using an identity language in a group, you may say:

("How about letting me use your pen?)" the form let sign the existence the feeling of solidarity among the speaker and hearer. But, this strategy still has risks to be refused if the hearer has different social level with us. In this case, the strategy of politeness, however, is more appropriately used.

Negative politeness strategy is not always intended to be used in a bad way. In fact, this strategy is not intended to improve negative fact threatening the hearer. We can ask for help indirectly by asking a question "Could you lend me a pen? Or "”Sorry to bother you, but 
may I borrow your pen?". The questions are preceded by expressions of apology to give some load showing our concern with the loss for hearer. This paper will study politeness in using language in the Diana Palmer's Cattleman's Pride by giving an emphasis on positive and negative face aspects.

\section{METHODOLOGY}

The study was conducted using qualitative content analysis method, and attempted to analyze the translation of positive and negative face in the Diana Palmer's Cattleman's Pride in order to know whether the translator may rightly identify the proper referents. In order to get the data, the researcher read the source text many times, identified the aspects wanted to be found, and then found out their translation in the Indonesian version. Then they were classified into the forms and then shifts or deviations were explained.

\section{III.FINDINGS AND DISCUSSION}

\section{Positive Face}

Jordan:I don't like being chased by women. I know you can't keep your eyes off me, but that's no excuse to come sashaying up to my front door looking for attention."

Libby:"Fat chance," she drawled, her green eyes twinkling up at him. "If I want a man, I'll try someone accessible, like a movie star or a billionaire...."

Jordan: aku tidak suka dikejar kejar wanita. Aku tahu kau tidak bisa behenti menatapku, tapi itu bukan alasan untuk datang kemari dan melenggak lenggok di depan pintuku untuk mencari perhatian

Libby: yang benar saja, bila aku menginginkan seorang pria, aku akan mencari orang yang lebih mudah untuk digapai, misalnya bintang film atau miliuner.

According to the writer, the above dialogue is a positive face in a joking category, since the expression of Jordan "I don't like being chased by women. I know you can't keep your eyes off $m e$ " is an expression of his kidding to Libby showing their intimacy among them, who are neighbors. This can be seen from Libby's answer: : "If I want a man, I'll try someone accessible,like a movie star or a billionaire...." showing that Libby is never angry with Jordan's anger and she answers it with the same expression: kidding.

From the translation aspect, this is included in free translation. But there are some parts omitted such as the sentence $I$ will try is not included in translation. Then if I want a man is translated into jika aku akan mencari orang which it should be translated into jika aku menginginkan laki-laki.since mencari orang is too general. Mean while accessible is properly translated. 
Libby: "Do you ever cry?"

Jordan :"Bite your tongue, woman," he said at her temple. "What would happen to the ranch if I sat down and bawled every time something went wrong? Tears won't come out of Persian carpet, you just ask my aunt!"

Libby: "Apa kau pernah menangis?"

Jordan: "jaga ucapanmu, Nona" " apa yang akan terjadi dipeternakan ini bila aku duduk dan meraung raung setiap kali ada masalah? Airmata tidak akan dapat berubah jadi karpet persia, kau boleh tanya tanteku"

The Libby's expression "Do you ever cry?" is not mocking viewed from its contexts

but it shows his mocking to Jordan. It is a positive face category showing the intimacy among them. it can also be seen from the answer Jordan gave "bite your tongue woman,......" which does not show his anger. Bite your tongue here is an idiom and the translation is jaga исарапти, it is better if the translation is jaga mulutmu. Due to politeness consideration, the translation is jaga ucapanmu instead of jaga mulutmu.

Jordan: "Five minutes left and even I'm not that good," he added. "Pity. If you hadn't

kept running your mouth, by now we could have..."

Libby: "You hush, Jordan Powell!" she shot at him. "Honestly, of all the blatant, arrogant, sex-crazed ranchers in Texas...!"

Jordan : waktuku tinggal 5 menit lagi. Sangat disayangkan bahkan aku tidak memiliki kinerja sebaik itu, tambahnya. Sayang sekali. Padahal kalau kau tidak sibuk bicara dengan mulutmu, saat ini kita sudah bisa..."

Libby: “ tutup mulutmu Jordan Powell!" Libby membentak pria itu, “ kau memang benar benar...orang texas sombong, tukang buat onar, gila seks....!"

The above dialogue in general seems not to be appropriate made by a man and a woman. It is proved from the answer Libby gave "You hush, Jordan Powell!..........." showing anger. But if the dialogue is observed deeply, there is no any occurrence showing their anger, but this merely showed their intimacy. It is a category of positive face in under sub category of kidding. In general the translation is free in nature, meaning that it is the meaning that is given priority instead of form.

Libby: "Nice to be so superior," she teased, eyes twinkling. Never to make mistakes..."

Curt: "You don't even stick your toes in the water, so don't lecture me about drowning."

Libby:" menyenangkan sekali menjadi orang mulia,tidak pernah melakukan kesalahan..."

Curt:"Kau bahkan tidak pernah mencoba masuk ke air, jadi jangan sok mengajariku tentang tenggelam."

The above dialogue is made by Libby and Curt, who are brothers. The dialogue shows their intimacy where the younger sister teased his elder brother with expression of "Nice to be so superior,........." and the elder answered it in equivalent answer. The word superior is 
translated into mulia, and stick your toes in the water is translated into tidak pernah mencoba masuk ke air, from the acceptability point of view the translation is adequate.

Libby: "I wish I had a camera," she called. "Mama Powell, protecting his babies..."

Jordan:"You watch it!" he retorted, shaking a finger at her.

She laughed. "What are you going to do, jump the fence and run me down?"

Libby:"andai saja aku membawa kamera,"teriaknya. "Mama Powel, sedang menjaga bayi-bayinya...."

Jordan:"Jaga ucapanmu!'jawab Jordan dengan pedas, sambil menggerakkan salah satu jarinya kearah Libby.

Libby tergelak:"Apa yang akan kau lakukan? melompati pagar dan menubrukku?"

Libby’s expression seems to tease " ...... "Mama Powell, protecting his babies..." and

Jordan responded it angrily "You watch it!" he retorted....., which is responded by Libby “ She laughed..... "What are you going to do......". This shows their intimacy. It is a positive face under category of joking. From the translation aspect, this is included in free translation. The translation of the dialog is good enough. Since it is easy to undertand and the acceptability is adequate.

Jordan: "You don't look too bad when you fix up," he commented,

Libby: "You don't look too bad when you don't," she replied. ' 'What uncomfortable answers are you getting?"

Jordan:"ternyata kau tidak terlalu jelek bila berdandan."

Libby:" kau juga tidak terlalu jelek meski tidak berdandan." Jawaban apa yang

kau dapatkan hingga membuatmu merasa tidak nyaman?

The dialogue is a positive face under category of joking since Jordan's expression" You don't look too bad when you fix up, maupun respon Libby, "You don't look too bad when you don't,,,," is not intended to insult, but because of their intimacy.

From the translation aspect, this is included in free translation. But there is an additional part hingga membuatmu merasa tidak nyaman? in the tanslation that is not found in the source text. However, at the best of my knowledge, is allowed since this addition is merely intended to make the translation better, having the same effect as the original.

Libby:"'Want some coffee?"

Jordan: "I'd love some. Eggs? Bacon? Cinnamon toast?" he added.

"Oh, I see," she mused with a grin. "Amie's gone and you're starving, huh?"

He shrugged nonchalantly. "She didn't have to leave. I only yelled a little."

"You shouldn't scare her. She's old."

"Dirt's old. Amie's a spring chicken." He chuckled.

Libby:"mau minum kopi?"

Jordan:"mau. Telur? Bacon? Roti panggang bumbu kayu manis?

Libby:" oh aku tahu, Amie sedang pergi dan kau kelaparan, ya?"

Jordan mengangkat bahu dengan sikap tidak acuh, " dia tidak perlu pergi, aku hanya berteriak sedikit padanya."

Libby:" seharusnya kau tidak membuatnya takut. Dia sudah tua." 